\title{
PERFORMANCE OF FLUID BALANCE AS A MARKER OF ACUTE KIDNEY INJURY IN CHILDREN AFTER OPEN HEART SURGERY
}

\author{
Jēkabs Krastiṇš ${ }^{1, \#}$, Aigars Pētersons ${ }^{2}$, and Aivars Pētersons ${ }^{3}$ \\ ${ }^{1}$ Clinic of Anesthesiology and Intensive Care, Children's Clinical University Hospital, 45 Vienïbas Ave., Rīga, LV-1004, LATVIA \\ 2 Department of Pediatric Surgery, Rīga Stradinš̌ University, 16 Dzirciema Str., Rīga, LV-1007, LATVIA \\ ${ }^{3}$ Department of Internal Diseases, Rīga Stradinš University, 16 Dzirciema Str., Rīga, LV-1007, LATVIA \\ \# Corresponding author, krajek@inbox.lv
}

Contributed by Aigars Pētersons

\begin{abstract}
Acute kidney injury (AKI) is a serious complication in the perioperative period and is consistently associated with increased morbidity and case fatality rate. This has been best studied in the cardiac surgery setting where it has been shown that up to $11.5-86.0 \%$ of patients exposed to cardiopulmonary bypass (CPB) will develop AKI, with 2.0-18.9\% requiring renal replacement therapy (RRT). A prospective uncontrolled cohort study was conducted between 2011 and 2015, in which 93 children with various congenital heart lesions undergoing CPB were enrolled. Serum creatinine (SCr) level was determined by Jaffé's method (Cobas 6000 analyser, Roche). Postoperative fluid balance was estimated as the difference between fluid intake and output. Data for further processing were retrieved from anaesthesia and intensive care data management system flowsheets (IntelliView, Philips). AKI developed in 42 patients (45.6\%) by meeting at least KDIGO (Kidney Disease: Improving Global Outcomes) stage I criteria (with SCr rise by more than 50\% from the baseline). Thirty eight patients complied with the $1^{\text {st }}$ stage of AKI, three with $2^{\text {nd }}$ stage and two with $3^{r d}$ stage, according the KDIGO classification and staging system. One patient having severity stage II and two patients having severity stage III of AKI required initiation of RRT using peritoneal dialysis. Two patients from the RRT group survived, one died. The median intraoperative urine output was $2.32 \mathrm{ml} / \mathrm{kg} / \mathrm{h}$, (range from $0.42-5.87 \mathrm{ml} / \mathrm{kg} / \mathrm{h}$ ). Median CPB time was 163 min., median aortic cross-clamping time was 97.9 min., cooling during $C P B$ to $29.5{ }^{\circ} \mathrm{C}$. The diagnosis of AKI using SCr was delayed by 48 hours after CPB. Median fluid balance (FB) on the first postoperative day in non-AKI patients was $13.58 \mathrm{ml} / \mathrm{kg}$ (IQR 0-37.02) vs $49.38 \mathrm{ml} / \mathrm{kg}$ (IQR 13.20-69.32) in AKI patients, $\mathrm{p}<0.001$. AKI is a frequent complication after open heart surgery in children with congenital heart lesions. From 93 patients included in the study, 42 (45.2\%) met at least KDIGO Stage I criteria for AKI. FB is a sensitive marker of kidney dysfunction. Median FB in the 1st postoperative day significantly differed between AKI patients: $49.38 \mathrm{ml} / \mathrm{kg}$ (13.20-69.32) versus $13.58 \mathrm{ml} / \mathrm{kg}$ in patients with intact kidney function $(A \cup C=0.84 ; \mathrm{p}=0.001$ ). Thus it can be used as a marker of AKI.
\end{abstract}

Key words: acute kidney injury, fluid balance, paediatric open-heart surgery.

\section{INTRODUCTION}

Acute kidney injury (AKI) is a serious complication in the perioperative period and is consistently associated with increased morbidity and case fatality rate. This has been best studied in the cardiac surgery setting where it has been shown that up to $11.5-86 \%$ of patients exposed to cardiopulmonary bypass (CPB) will develop AKI, with $2-18.9 \%$ requiring renal replacement therapy (RRT). Depending on the criteria used to define AKI and the postoperative period studied, mortality ranges from $1 \%$ to $30 \%$, although this is consistently higher, approaching $80 \%$, if RRT is required. AKI may contribute to chronic kidney disease and negative long-term health outcomes. There is no clear understanding of the pathogenesis of CPB associated AKI and no effective treatment or prevention has yet been established for this 
syndrome. Fluid overload (FO), which often accompanies significant AKI, was first recognised in a retrospective study of paediatric bone marrow transplant patients (Lane $e t$ al., 1994). Studies of adult critically ill patients have shown that positive FB above $10 \%$ is associated with higher long-term mortality and higher occurrence of AKI, thus indicating this threshold as a potential indicator of adverse outcome (Van Biesen et al. 2005). The study of Hassinger et al. showed that patients with early positive $\mathrm{FB}$, more than $5 \%$ by the end of POD 1, were more likely to develop AKI (43.3\% vs $33.8 \%, p=0.023)$. The authors also observed that positive FB was associated with a prolonged lengths of hospital stay (3.5 more days in the hospital), two more days on inotropes, and increased prevalence of prolonged mechanical ventilation (Hassinger et al., 2014).

\section{MATERIALS AND METHODS}

Children undergoing elective CPB for surgical correction or palliation of congenital heart lesions between January 2011 and June 2015 were prospectively enrolled. Exclusion criteria included preexisting renal dysfunction. Renal dysfunction was defined as a SCr level that was greater than the 90th percentile for the child's age and gender. Patients with a history of potential nephrotoxin use during the preoperative day were excluded because of potential confounding effects. Ethical approval was obtained from the Ethics Committee of the Children's Clinical University Hospital.

Creatinine concentrations were measured in the hospital's clinical chemical laboratory using Jaffes method on a Cobas 8000 analyser. The primary outcome variable was the development of AKI. AKI was defined according to the KDIGO classification and staging system based on urine output and SCr level: Stage I was SCr 1.5-1.9 times baseline $\geq 26.5 \mu \mathrm{mol} / \mathrm{L}$ increase or UO $<0.5 \mathrm{ml} / \mathrm{kg} / \mathrm{h}$ for $6-12$ hours, stage II was SCr 2-2.9 times baseline and UO $<0.5$ $\mathrm{ml} / \mathrm{kg} / \mathrm{h}$ for $\geq 12$ hours, stage III was SCr 3 times baseline or $\geq 354 \mu \mathrm{mol} / \mathrm{L}$ and/or UO $<0.3 \mathrm{ml} / \mathrm{kg} / \mathrm{h}$ for $\geq 24$ hours OR anuria for $\geq 12$ hours (Kellum et al., 2012).

Intraoperative fluid intake was assessed by total of intravenous fluid volume, cardioplegia volume, and pump volume (total volume added during cardiopulmonary bypass plus reservoir volume at the start of cardiopulmonary bypass minus reservoir volume at the termination of cardiopulmonary bypass). Intraoperative fluid output was the total of urine produced on cardiopulmonary bypass, chest tube drainage before the patient left the operating room, and estimated blood loss. Intraoperative net fluid balance was the difference between fluid intake and output. Data for further processing were retrieved from anaesthesia and intensive care data management IntelliView Clinical Information Portfolio (Philips) system flowsheets (Fig. 1). Similarly, fluid balance was calculated after the completion of surgical repair. Patient data were collected from day of admission to Intensive care (denoted as POD-1).

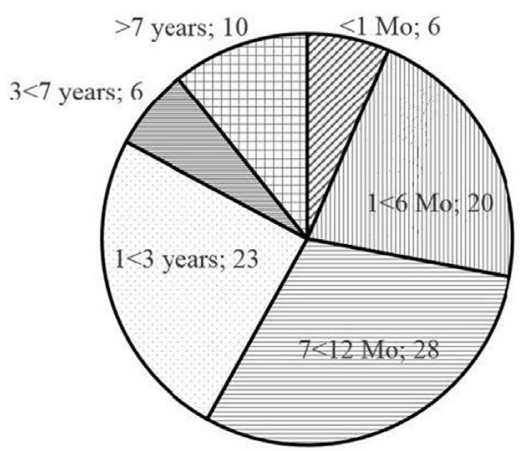

Fig. 1. Age distribution of patients.
Sample collection and processing. Creatinine concentrations were measured in the hospital's clinical chemical laboratory by Jaffes method on a Cobas 8000 analyser. All samples were obtained at the following time points: (1) preoperative; (2) 24 hours and (3) 48 hours after the surgical repair. The primary outcome variable was the development of AKI. AKI was defined according to the KDIGO classification and staging system based on urine output and $\mathrm{SCr}$ level: Stage I was SCr 1.5-1.9 times baseline $\geq 26.5 \mu \mathrm{mol} / \mathrm{L}$ increase or UO $<0.5 \mathrm{ml} / \mathrm{kg} / \mathrm{h}$ for $6-12$ hours, stage II was SCr 2-2.9 times baseline and UO $<0.5 \mathrm{ml} / \mathrm{kg} / \mathrm{h}$ for $\geq 12$ hours, stage III was SCr 3 times baseline or $\geq 354 \mu \mathrm{mol} / 1$ and/or UO $0.3 \mathrm{ml} / \mathrm{kg} / \mathrm{h}$ for $\geq 24$ hours OR anuria for $\geq 12$ hours (Kellum et al., 2012). Recorded variables included age, gender, CPB time, lowest temperature during $\mathrm{CPB}$ and urine output, doses of diuretics, inotropes and vasopressors, and postoperative fluid balance. Outcome variables included percent change in serum creatinine, days in AKI, dialysis requirement, duration of $\mathrm{MV}$, lengths of stay in ICU and hospital LOS.

Anaesthesia management. Induction to anaesthesia was provided using inhalation of Sevoflurane by face mask or intravenously by Propofol or Midazolam in combination with Ketamine. Anaesthesia was maintained at (0.8-1.0 minimal alveolar concentration) of sevoflurane and fentanyl (3-5 $\mu \mathrm{g}$ $\mathrm{kg} / \mathrm{h}$ ) using a Primus anaesthesia machine (Drãger Medical, Lübeck, Germany). Muscle relaxation was achieved with pipecuronium $(0.6 \mathrm{mg} / \mathrm{kg})$. During $\mathrm{CPB}$, isoflurane was applied via the $\mathrm{CPB}$ circuit. All patients were ventilated in a volume-controlled mode; with a tidal volume of $6 \mathrm{ml} / \mathrm{kg}$ and respiratory rate adjusted to achieve normocapnia. The heart-lung machine SORIN S 5 (LivaNova, United Kingdom) with a membrane oxygenator Affinity Pixie ( Oxygenatior (Medrtronics, USA) was used for neonates, infants and small children requiring cardiopulmonary bypass at flow rates up to $2.0 \mathrm{~L} / \mathrm{min}$. For older patients Terumo, Medtronic C oxygenator with CPB circuit was used. Surgical procedures were performed with CPB in moderate hypothermia. Cardioplegic arrest was achieved by cold blood cardioplegia and repeated every 20 minutes. Nonpulsatile perfusion was performed during CPB. Pump flow, oxygen flow, and MAP were adjusted to maintain $\mathrm{ScvO}_{2}$ levels within the preoperative range and at least higher than $50 \%$ absolute. In patients monitored with a pulmonary artery catheter (PAC), haemodynamic therapy was titrated to achieve car- 
diac index $>2.2 \mathrm{~L} / \mathrm{min} / \mathrm{m} 2$ and mixed venous oxygen saturation $\left(\mathrm{Sv} \mathrm{O}_{2}\right)$ greater than $65 \%$.

Fluid therapy was performed with balanced crystalloid (Lactated Ringers solution, Sterofundin VG, BBraun; Melsungen, Germany). The pump prime consisted of various amounts of Ringer lactate and whole blood, depending on estimated blood volume, haematocrit, and total priming volume used. Hypothermic myocardial protection was provided by core cooling at flow rates of 150 to $200 \mathrm{ml} / \mathrm{kg}$ / min. (2.0 to $3.0 \mathrm{~kg}$ ) or 100 to $150 \mathrm{ml} / \mathrm{kg} / \mathrm{min}$. (3.0 to $5.0 \mathrm{~kg}$ ) to rectal and esophageal temperatures of $\leq 30^{\circ} \mathrm{C}$, followed by aortic cross clamping. Once optimal hypothermic temperatures were reached, continuous low-flow cardiopulmonary bypass was instituted during completion of intracardiac stage. Core rewarming was instituted during completion of the intracardial stage. Mean perfusion pressures were maintained between $30 \mathrm{~mm} \mathrm{Hg}$ and $70 \mathrm{~mm} \mathrm{Hg}$ during rewarming. All patients were weaned from cardiopulmonary bypass after the rectal temperature reached $35{ }^{\circ} \mathrm{C}$. Lactated Ringers, fresh whole blood, blood products, and increased inotropic support were given as necessary to maintain normal filling pressures and a systolic perfusion pressure of at least $60 \mathrm{~mm} \mathrm{Hg}$.

Postoperative management. Analgesia and sedation were provided by a continuous fentanyl or morphine infusion, typically $2-4 \mu \mathrm{g} \mathrm{kg}^{-1} \cdot \mathrm{h}^{-1}$ and Midazolam or Dexmedetomidine. Routine continuous postoperative monitoring included the surface ECG, transcutaneous pulse oximetry, pulmonary arterial and right and left atrial pressures (through transthoracic catheters), and systemic arterial pressure. Inotropic, chronotropic, and afterload reducing agents were used as clinically indicated. Vasoactive medications were typically started in the operating room at the discretion of the attending cardiac surgeon and anaesthesiologist based on individual patient characteristics, including, residual lesions, transesophageal echocardiographic findings, and physiological status. On arrival to the ICU, medications are adjusted by the bedside nurse under the direction of the ICU team. Patients with hypotension typically receive norepinephrine and epinephrine initially, volume infusions (plasma or $5 \%$ albumin) were given to maintain adequate filling pressures with systolic perfusion pressures of at least 50 $\mathrm{mm} \mathrm{Hg}$. Diuretics (usually furosemide 1 to $2 \mathrm{mg} / \mathrm{kg}$ per dose, two to four times daily) were prescribed at the attending physician's discretion if a targeted fluid balance or urine output of $>0.5 \mathrm{ml} / \mathrm{kg} /$ hour could not be achieved. Some patients received continuous infusion of Furosemide and Aminophilline.

During the study continuous fentanyl or morphine infusions were discontinued on the first postoperative morning in the haemodynamically stable patient or continued for longer periods as dictated by the clinical status of the patient. Mechanic ventilation was provided with a Viasys Avea ventilator (Cardinal Health, USA) at the mode suitable for specific cardiac lesion. The rate of weaning of mechanical ventilation was determined by the patient's fluid balance and gas exchange as indicated by arterial blood sampling, pattern of breathing, and daily radiographic findings.

The initial mode of ventilation was pressure-regulated volume control in all patients. Once the patient was breathing spontaneously and ready for weaning, the ventilator mode was switched to pressure-controlled, synchronised, intermittent, mandatory ventilation.

The criteria for extubation was protocolised, as follows: stable haemodynamic profile, normal cardiac rhythm, adequate oxygenation on fraction of inspired oxygen $<0.4$, maintenance of a $\mathrm{pH}>7.35$, and $\mathrm{PacCO}_{2}<45 \mathrm{~mm} \mathrm{Hg}$ on continuous positive airway pressure $<6 \mathrm{~cm} \mathrm{H}_{2} \mathrm{O}$ with pressure support $<8 \mathrm{~cm} \mathrm{H}_{2} \mathrm{O}$ for at least $1 \mathrm{~h}$, the level of consciousness consistent with adequate airway protective reflexes, absence of accessory respiratory muscle recruitment, and approval by the attending intensivists. Corticosteroids were routinely administrated 4 to $6 \mathrm{~h}$ before extubation. All patients were monitored with invasive arterial and central blood pressure monitoring. In patients undergoing complex cardiac surgery, a left atrial or pulmonary artery catheter was inserted during surgical repair. Transesophageal echocardiography was performed in all valve surgery cases. Cerebral oxygen saturation $\left(\mathrm{ScO}_{2}\right)$ was determined in all patients with an INVOS 5100 monitor (Somanetics, Troy, USA). All patients received routine standard care during the study period, which included the use of dextrose-containing crystalloid solutions (Sterofundin HEG, Sterofundin BG, Sterofundin VG (BBraun, Melsungen, 50-80 ml/kg/day) during the first 24-48 hours postoperatively, followed by the initiation of enteral tube feeding.

Statistical methods. Unless indicated otherwise, continuous data are expressed as median values with interquartile range (IQR) and discrete data as numbers with percentages (\%). Patients were grouped according to whether they lacked AKI or had AKI within 48 hours following CPB. Clinical characteristics and biomarker levels were compared between AKI and non-AKI patients using the Student's $t$ test for normally distributed continuous variables. The Mann-Whitney U test was performed for non-normally distributed continuous variables and Pearson's $\chi^{2}$ or Fisher's exact test (as appropriate) was performed on all categorical variables. Statistical significance was defined as a probability value less than 0.05 . Univariate logistic analysis was performed to examine the relationship between multiple clinical variables as well as the presence of AKI and clinical outcomes (ICU length of stay, hospital length of stay, duration of mechanical ventilation, and in-hospital mortality). Variables with a probability value less than 0.1 were then cast into a multivariate logistic regression analysis. Odds ratio, CI, and probability values were calculated. All univariate and multivariate logistic regression analyses were conducted for the entire cohort. Receiver operating characteristics (ROC) curves were generated for the occurrence of AKI within 48 hours following cardiopulmonary bypass using FB at POD-1. The areas under the curve (AUC), with $95 \%$ confidence intervals $(95 \% \mathrm{CI})$, were calculated. Also, the optimal cut-off value was calculated with corresponding 
sensitivity and specificity. Using those cut-off values, sensitivity and specificity of FB for predicting AKI were calculated for patients who developed AKI. Two-sided $p=0.05$ was considered the limit of significance in all analyses. Data were analysed using IBM SPSS statistics version 21 (Statistical Package for the Social Sciences, Chicago, IL).

\section{RESULTS}

Median age of patients was ten months, and body weight was $7.6 \mathrm{~kg}$ (Table 1). The majority from 93 included patients $54(58.00 \%)$ were less than 12 months old, 6 patients $(6.45 \%)$ were less than 1 months old, $20(21.51 \%)$ patients were between 1 and 6 months of age; and 28 (30.11\%) patients had age of 7 to 12 months were. Age group of 1 to 3 years represents $23(24.73 \%)$ children. $6.45 \%$ were patients between 3 to 7 years, and $10.75 \%$ were older than 7 years, (Fig. 2, Table 2). Types of congenital heart lesions are summarised in Table 3.

Postoperative AKI occurred in 42 (45.16\%) of 93 children. Thirty-seven of them reached severity stage I according the KDIGO classification and stating system, three reached stage II and two reached stage III, based on $\mathrm{SCr}$ and (or)

Table 1 DEMOGRAPHIC DATA

\begin{tabular}{lcccc}
\hline \multicolumn{1}{c}{ Variable } & Median & IQR (Q1-Q3) & Range \\
\hline Age, months & 10.0 & $6.0-17$ & $0.2-180.0$ \\
Body weight $(\mathrm{kg})$ & 7.6 & $5.6-10$ & $2.6-60.0$ \\
M/F ratio: & & & \\
35/58 & & &
\end{tabular}

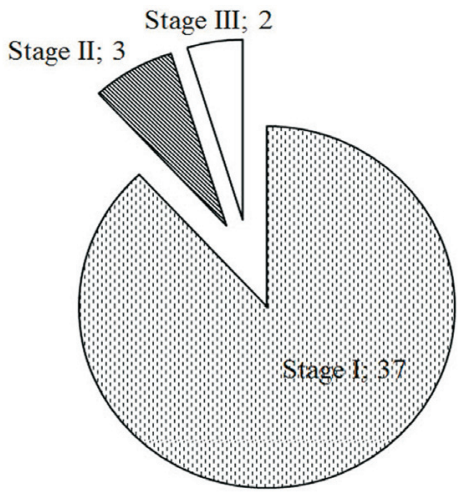

Fig. 2. Severity of acute kidney injury.

Table 2

AGE STRUCTURE

\begin{tabular}{lcc}
\hline \multicolumn{1}{c|}{ Age group } & Number of patients & $(\%)$ \\
\hline Less than 1 month & 6 & 6.45 \\
$1<6$ months & 20 & 21.51 \\
$7<12$ months & 28 & 30.11 \\
$1<3$ years & 23 & 24.73 \\
$3<7$ years & 6 & 6.45 \\
7 years and older & 10 & 10.75 \\
Total: & 93 & 100.00
\end{tabular}

urine output criteria (Fig. 3). Fig. 4 shows changes in $\%$ from the baseline $\mathrm{SCr}$ concentration to maximum during 48 hours. It shows number of patients for each AKI severity stage.

Postoperative fluid balance (FB POD-1) was $13.58 \mathrm{ml} / \mathrm{kg}$ (median) in the non-AKI group versus $27.20 \mathrm{ml} / \mathrm{kg}$ in the AKI group, $p=0.025$ (Fig. 5, Table 4). In addition, FB was calculated separately according the severity stage of AKI.

Table 3

TYPES OF SURGICAL INTERVENTION

\begin{tabular}{l|c|c}
\hline \multicolumn{1}{c|}{ Surgical intervention } & $\begin{array}{c}\text { Number of } \\
\text { patients }\end{array}$ & $\%$ \\
\hline AVSD (atrioventricular septal defect) repair & 20 & 21.51 \\
DORV (double outlet right ventricle) & 3 & 3.23 \\
Pulmonary stenosis repair & 5 & 5.38 \\
Tricuspid regurgitation repair & 2 & 2.15 \\
Unifocalization procedure & 2 & 2.15 \\
Aortic stenosis repair & 3 & 3.23 \\
VSD (ventricular septal defect) repair & 37 & 39.78 \\
Mitral valve plastics & 2 & 2.15 \\
TAPVD (total anomalous pulmonary vein drainage) & 4 & 4.30 \\
TGA (transposition of great arteries) & 6 & 6.45 \\
TOF (tetralogy of Fallot) & 9 & 9.68 \\
Total: & 93 & 100.00
\end{tabular}

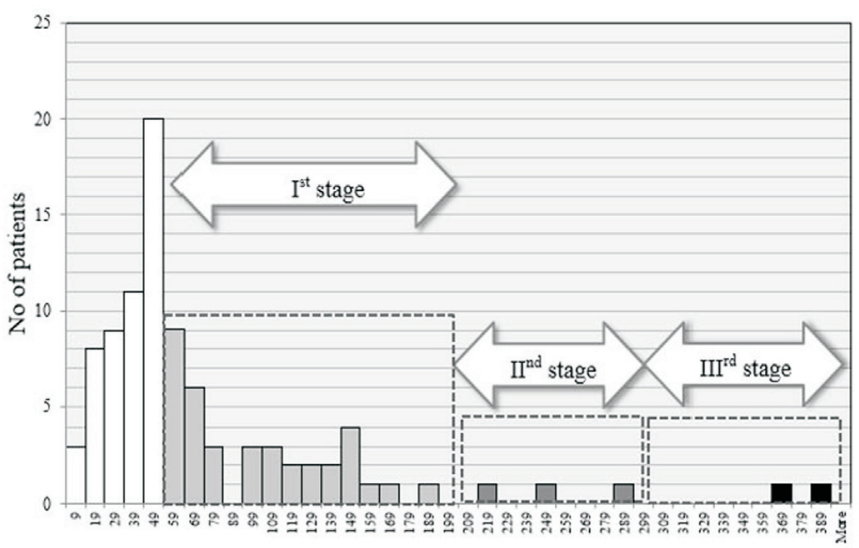

Fig. 3. $\Delta \mathrm{SCr}$ (serum creatinine) histogram.

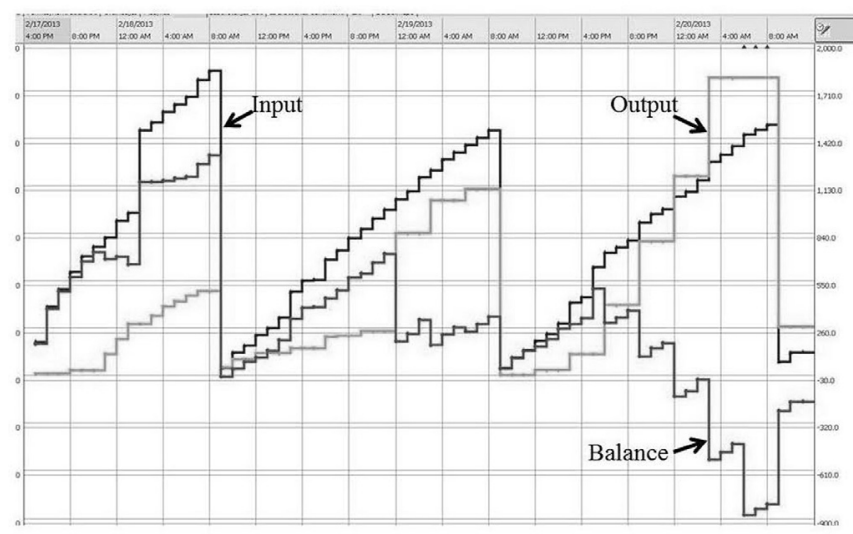

Fig. 4. Postoperative fluid balance (screenshot from the ICIP (Philips) patient data management system). 


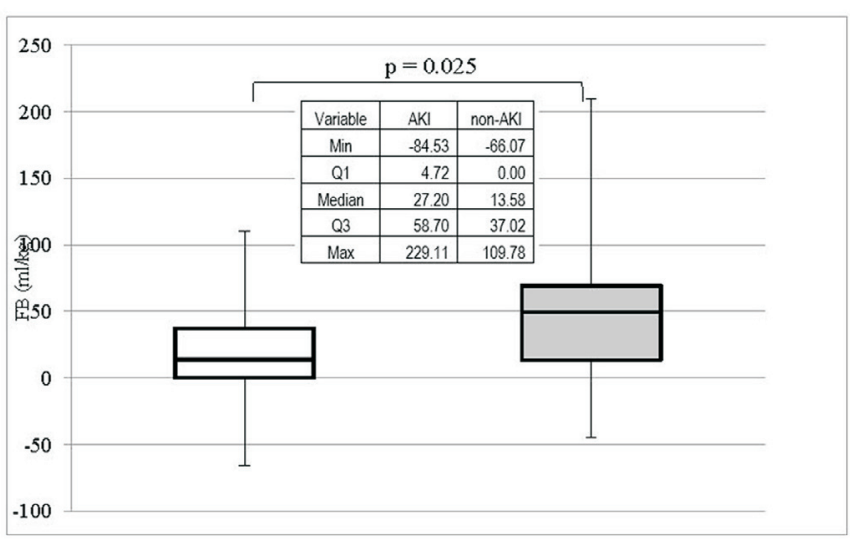

Fig. 5. Fluid balance (FB) at POD-1 (patient data collected from day of admission to intensive care) in acute kidney injury (AKI) and non-AKI patients. Box and whisker plot showing FB ( $\mathrm{ml} / \mathrm{kg}$ ) in AKI (filled box) and non-AKI (empty box) patients.

Table 4

CLINICAL OUTCOME CHARACTERISTICS BY AKI STATUS

\begin{tabular}{ccccc}
\hline Variable/category & Non-AKI & AKI & $p$ value \\
\hline FB POD-1 ml/kg, median (IQR) & 13.58 & 27.20 & $0.025^{*}$ \\
& $(0.00-37.02)$ & $(4.72-58.70)$ & \\
FB POD-1 $\geq 50 \mathrm{ml} / \mathrm{kg}, \mathrm{n}(\%)$ & $18 / 51(35.29 \%)$ & $25 / 42(59.52 \%)$ & $0.046^{\#}$
\end{tabular}

\#Fisher's exact test, *Mann-Whitney U test

Fluid balance in patients reaching $1^{\text {st }}$ stage of AKI severity increased from $13.58 \mathrm{ml} / \mathrm{kg}$ (median) to $26.27 \mathrm{ml} / \mathrm{kg}, 2^{\text {nd }}$ stage to $36.29 \mathrm{ml} / \mathrm{kg}$ and $3^{\text {rd }}$ stage to $90.09 \mathrm{ml} / \mathrm{kg}$, ANOVA test $p=0.002$ (Fig. 6). To evaluate postoperative fluid balance as a marker for AKI, ROC analysis was performed (Fig. 7). AUC was 0.842 (CI 95\% 0.838-0.926), sensitivity of $80 \%$, specificity of $71 \%$ and cut-off value of $25 \mathrm{ml} / \mathrm{kg}$.

\section{DISCUSSION}

Studies of paediatric patients requiring RRT showed correlation of the degree of positive FB with poor outcome and mortality, hinting at a dynamic positive FB value for predicting adverse outcomes, with the $10 \%$ cut-off value proving to be clinically significant (Horiguchi et al., 2014). Infants 72 hours after cardiac surgery with a positive fluid balance had 10 times higher odds of prolonged mechanical ventilation than infants without a positive fluid balance (Shi et al., 2008). Patients with $\geq 20 \%$ fluid overload had an 8.5 -fold greater adjusted odds ratio of death than those with less than $20 \%$ fluid overload (Sutherland et al., 2010). A recent study by Hassinger et al. (2014) also demonstrated that increasing positive FB, as measured by daily fluid balance, is associated with worse outcome following congenital heart

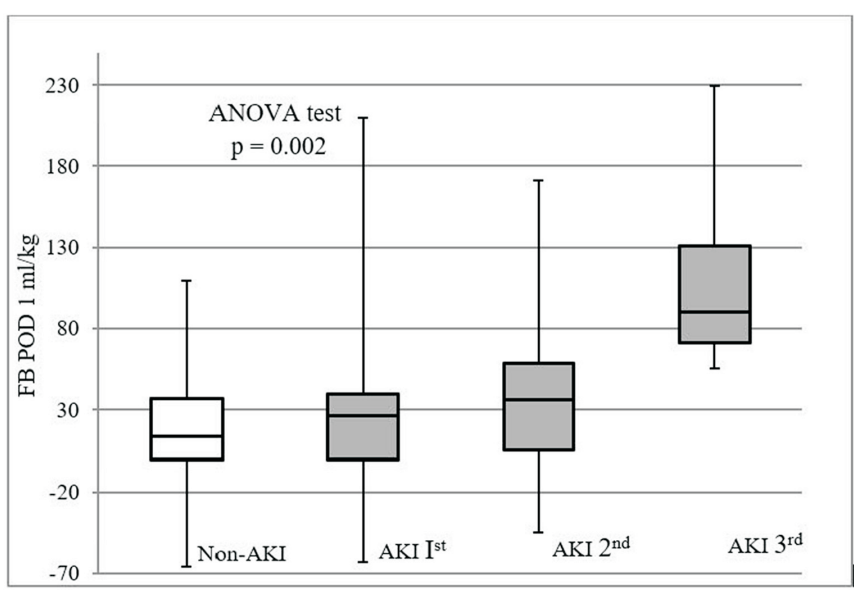

Fig. 6. Postoperative fluid balance (FB) and severity of acute kidney injury (AKI). Box and whisker plot showing FB POD-1 in non-AKI patients (empty box) and patients having $\mathrm{I}^{\mathrm{st}}, 2^{\text {nd }}$ and $3^{\text {rd }}$ stage of AKI (filled boxes).

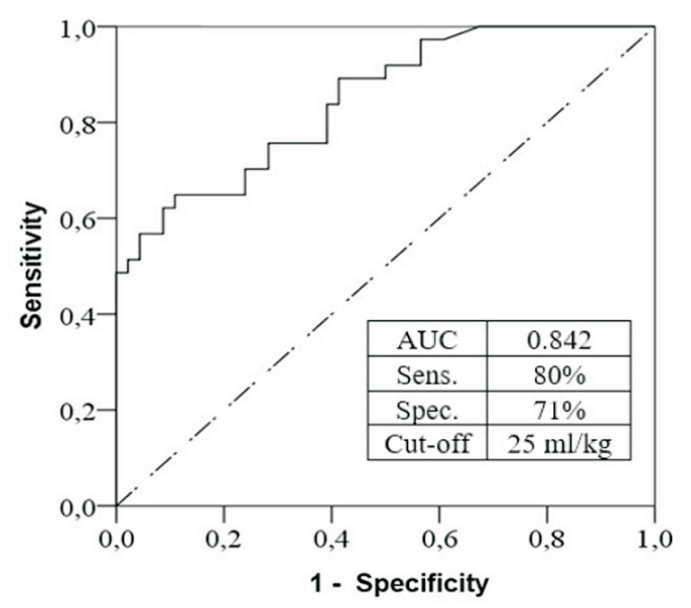

Fig. 7. Receiver operating characteristics curve of fluid balance POD-1 in acute kidney injury (AKI) and non-AKI patients.

surgery in infants. In the study of Lex et al. (2016), where postoperative FB was analysed in 1520 paediatric patients after open heart surgery, there was a positive FB between $5 \%$ and $10 \%$ in 120 patients $(7.8 \%)$, and in 33 patients (2.1\%) FB was above $10 \%$. Multivariable analysis showed that higher fluid overload on the day of the surgery was independently associated with mortality (adjusted odds ratio, 1.14; 95\% CI, 1.008-1.303; $p=0.041$ ) and low cardiac output syndrome (adjusted odds ratio, 1.21; 95\% CI, $1.12-1.30 ; p=0.001)$. Higher maximum SCys C levels (adjusted odds ratio, 1.01; 95\% CI, 1.003-1.021; $p=0.009$ ), maximum vasoactive-inotropic scores (adjusted odds ratio, $1.01 ; 95 \%$ CI, 1.005-1.029; $p=0.042$ ), and higher blood loss on the day of the surgery (adjusted odds ratio, 1.01; 95\% CI, 1.004-1.025; $p=0.015)$ were associated with a

POSTOPERATIVE FLUID BALANCE (ML/KG) AT POD-1 AND SEVERITY OF AK

\begin{tabular}{l|c|c|c}
\hline \multicolumn{1}{c|}{ Variable/Severity } & Non-AKI & AKI Ist stage & AKI IInd stage \\
\hline Median & 13.58 & 26.27 & 36.29 \\
Interquartile range (Q1-Q3) & $0-37.02$ & $0-39.63$ & 90.19 \\
\end{tabular}


higher risk of fluid overload that was greater than $5 \%$ (Lex et al., 2016).

The etiology of positive FB in this patient population is multifactorial. Cardiopulmonary bypass results in both haemodilution and increased capillary permeability, both of which promote extravasation of fluid into the extracellular fluid compartment (Zhang et al., 2004). Fluid resuscitation and blood product administration in the immediate postoperative period further contributes to third spacing. As body wall oedema increases, intra-abdominal pressure rises and renal perfusion pressure is decreased (Wauters et al., 2009). When combined with postoperative myocardial dysfunction, there is also a stimulus to retain fluid via the renin-angiotensin-aldosterone system (Sorof et al., 1999). Given the acute nature of CPB mediated kidney injury and the observation that most infants have normal renal function prior to surgery, these patients may be ideal candidates for aggressive postoperative goal-directed protocols aimed at minimisation of positive FB. Peritoneal dialysis has been shown to be a safe and effective method of fluid removal in postcardiotomy infants (Pedersen et al. 2008), and early initiation of this therapy can improve haemodynamics and ICU outcomes (Sorof et al., 1999).

By examining fluid balance early after cardiac surgery, the current study adds to the growing body of evidence that positive fluid balance is independently associated with kidney dysfunction. FB POD-1 $\geq 50 \mathrm{ml} / \mathrm{kg}$, in the non-AKI group was $35.29 \%$ versus $59.52 \%$ in AKI group, $p=0.046$ (Table 4). Median postoperative fluid balance in the non-AKI group was $13.58 \mathrm{ml} / \mathrm{kg}$ versus $27.20 \mathrm{ml} / \mathrm{kg}$ in the AKI group, $p=0.025$ (Table 4 , Fig. 5), OR of FB $\geq 50$ $\mathrm{ml} / \mathrm{kg}$ in AKI vs. non-AKI was 2.58 (CI 95\% 0.94-7.07), $p=0.026$. After performing ROC analysis, AUC of FB POD-1 was 0.842 with sensitivity of $80 \%$, specificity of $71 \%$ (CI 95\% 0.838-0.926) and cut-off value was $25 \mathrm{ml} / \mathrm{kg}$, $p=0.001$ (Fig. 7). Similar results were published in the study of Hassinger et al. (2014). They found postoperative positive fluid balance $>50 \mathrm{ml} / \mathrm{kg}$ in $31 \%$ of patients, which is less than in this study. The reported AUC was 0.963; 95\% CI, 0.916-1.000; $p=0.002$ (Hassinger et al., 2014).

\section{CONCLUSIONS}

Fluid balance is a suitable marker for the prediction of postoperative AKI. $35.29 \%$ patients had FB POD-1 $\geq 50 \mathrm{ml} / \mathrm{kg}$ in the non-AKI group had versus $59.52 \%$ in the AKI group, $p=0.046$. Median postoperative fluid balance in the non-AKI group was $13.58 \mathrm{ml} / \mathrm{kg}$ versus $27.20 \mathrm{ml} / \mathrm{kg}$ in the AKI group, $p=0.025$, OR of $\mathrm{FB} \geq 50 \mathrm{ml} / \mathrm{kg}$ in AKI versus non-AKI was 2.58 (CI 95\% 0.94-7.07), $p=0.06$. After performing ROC analysis, AUC of FB POD-1 was 0.842 with sensitivity of $80 \%$, specificity of $71 \%$ (CI 95\% $0.838-$
0.926 ) and the cut-off value was $25 \mathrm{ml} / \mathrm{kg}, p=0.001$. The role of fluid balance in the postoperative management is underestimated and daily FB monitoring now becomes essential.

\section{REFERENCES}

Bagshaw, S. M., Brophy, P. D., Cruz, D., Ronco, C. (2008). Fluid balance as a biomarker: Impact of fluid overload on outcome in critically ill patients with acute kidney injury. Crit. Care, 12 (4), 169.

Hassinger, A. B., Wald, E. L., Goodman, D. M. (2014). Early postoperative fluid overload precedes acute kidney injury and is associated with higher morbidity in pediatric cardiac surgery patients. Pediatr. Crit. Care Med., 15, 131-138.

Hazle, M. A., Gajarski, R. J., Yu, S., Donohue, J., Blatt, N. B. (2013). Fluid overload in infants following congenital heart surgery. Pediatr. Crit. Care Med., 14, 44-49.

Horiguchi, Y., Uchiyama, A., Iguchi, N., Sakai, K., Hiramatsu, D., Ueta, K., Ohta, N., Fujino, Y. (2014). Perioperative fluid balance affects staging of acute kidney injury in postsurgical patients: A retrospective case-control study. J. Intensive Care, 2 (1), 2-6.

Kellum, J. A., Lameire, N., Aspelin, P. et al. (2012). Kidney Disease: Improving Global Outcomes (KDIGO) Acute Kidney Injury Work Group. KDIGO Clinical Practice Guideline for Acute Kidney Injury. Kidney Int., 2, 1-138.

Lane, P. H., Mauer, S. M., Blazar, B. R., Ramsay, N. K., Kashtan, C. E. (1994). Outcome of dialysis for acute renal failure in pediatric bone marrow transplant patients. Bone Marrow Transplant., 13 (5), 613-617.

Lex, D. J., Tóth, R., Czobor, N. R., Alexander, S. I., Breuer, T., Sápi, E., Szatmári, A., Székely, E., Gál, J., Székely, A. (2016). Fluid overload is associated with higher mortality and morbidity in pediatric patients undergoing cardiac surgery. Pediatr. Crit. Care Med., 17, 307-314.

Pedersen, K. R., Hjortdal, V. E., Christensen, S., Pedersen, J., Hjortholm, K., Larsen, S. H., Povlsen, J. V. (2008). Clinical outcome in children with acute renal failure treated with peritoneal dialysis after surgery for congenital heart disease. Kidney Int., Suppl., S81-86.

Shi, S., Zhao, Z., Liu, X., Shu, Q., Tan, L., Lin, R., Shi, Z., Fang, X. (2008). Perioperative risk factors for prolonged mechanical ventilation following cardiac surgery in neonates and young infants. Chest, 134 (4), 768-774.

Sorof, J. M., Stromberg, D., Brewer, E. D., Feltes, T. F., Fraser, C. D., Jr. (1999). Early initiation of peritoneal dialysis after surgical repair of congenital heart disease. Pediatr. Nephrol., 13, 641-645.

Sutherland, S. M., Zappitelli, M., Alexander, S. R., et al. (2010). Fluid overload and mortality in children receiving continuous renal replacement therapy: The prospective pediatric continuous renal replacement therapy registry. Amer. J. Kidney Dis., 55 (2), 316-325.

Van Biesen, W., Yegenaga, I., Vanholder, R., Verbeke, F., Hoste, E., Colardyn, F., Lameire, N. (2005). Relationship between fluid status and its management on acute renal failure (ARF) in Intensive Care Unit (ICU) patients with sepsis: A prospective analysis. J. Nephrol., 18, 54-60.

Wauters, J., Claus, P., Brosens, N., McLaughlin, M., Malbrain, M., Wilmer, A. (2009). Pathophysiology of renal hemodynamics and renal cortical microcirculation in a porcine model of elevated intra-abdominal pressure. $J$ Trauma, 66, 713-719.

Zhang, S., Wang, S., Yao, S. (2004). Evidence for development of capillary leak syndrome associated with cardiopulmonary bypass in pediatric patients with the homozygous C4A null phenotype. Anesthesiology, 100, 1387-1393. 


\section{ŠĶIDRUMA BALANSA KĀ NIERU BOJĀJUMA MARĶIERA VEIKTSPĒJA BĒRNIEM PĒC SIRDSKAITES KOREKCIJAS M'ÁKSLİGĀ ASINSRITĒ}

Akūts nieru bojājums (ANB) ir nopietna pēcoperācijas perioda komplikācija, kas konsekventi saistīta ar pieaugošu morbiditāti un mortalitāti. Tas ir visvairāk pētîts kardiokirurǵijāā, kur pierādìts, ka līdz 11,5-86,0\% pacientu, kam veic operācijas MA (māslīgā asinsritē), attīstās ANB, 2,0-18,9\% no tiem nepieciešama nieru aizstājējterapija (NAT). Atkarībā no kritērijiem, ko izmanto, lai definētu ANB, mirstība svārstās no 1\% līdz 30\%, lai gan tas ir konsekventi augstāks, tuvojoties 80\%, ja ir nepieciešams NAT. ANB var veicināt hronisku nieru slimību un negatīvus ilgtermiṇa veselības rezultātus. Nav skaidri saprotama ar MA saistītā ANB patogenitāte, un šim sindromam vēl nav izstrādāta efektīva ārstēšana vai profilakse. 2011.-2015. gadā tika veikts prospektīvs nekontrolēts kohortas pētījums, kurā tika iekḷauti 93 bērni ar dažādām iedzimtām sirdskaitēm, kas tika korig̣ētas MA. Seruma kreatinīna (SCr) līmeni noteica ar Jaffé metodi (Cobas 6000 analizators, Roche), škiidruma balanss (ŠB) tika aprēkināts kā starpība starp kopējo ievadīto un izdalīto škidruma apjomu. Skaitliskie lielumu tika iegūti, izmantojot IntellyView intensīvās terapijas klīnisko informācijas sistēmu (Philips). ANB attīstījās 42 pacientiem (45,6\%), sasniedzot vismaz KDIGO I smaguma pakāpes kritērijus (ar SCr pieaugumu vairāk nekā 50\% no izejas koncentrācijas). 38 pacienti saskan̄ā ar KDIGO klasifikācijas sistēmu sasniedza II, bet divi pacienti sasniedza ANB III smaguma pakāpi. Vienam pacientam ar II smaguma pakāpi un diviem pacientiem, kuriem bija III smaguma pakāpe, bija nepieciešama NAT uzsākšana, izmantojot peritoneālo dialīzi. Divi pacienti no NAT grupas izdzīvoja, viens nomira. Mediānā intraoperatīvas urīna izvade bija 2,32 ml/kg/h (diapazons no 0,42-5,87 ml/kg/h). Vidējais MA laiks bija $163 \mathrm{~min}$, vidējais aortas oklūzijas laiks bija 97,9 min, hipotermija līdz $29,5^{\circ} \mathrm{C}$. ANB diagnoze, izmantojot SCr, aizkavējās 48 stundas pēc MA. Vidējais pozitīvais šķidruma balanss (ŠB) pirmajā pēcoperācijas dienā pacientiem ar intaktu nieru funkciju, bija 13,58 ml/kg (IQR 0,00-37,02) salīdzinājumā ar 49,38 ml/kg (IQR 13,20-69,32) pacientiem ar ANB, $p$ fs22 0,001 . AKI ir bieža komplikācija pēc sirdskaites korekcijas MA bērniem. No 93 pētījumā iekḷautajiem pacientiem 42 (45,2\%) atbilda vismaz KDIGO I pakāpes ANB kritērijiem. ŠB ir jutīgs nieru disfunkcijas marķieris. ŠB 1. pēcoperācijas dienā ir statistiski nozīmīga atšķirība starp pacientiem ar ANB 49,38 ml/kg (IQR 13,20-69,32) salīdzinājumā ar 13,58 ml/kg pacientiem ar intaktu nieru funkciju $($ AUC $=0,84 ; p=$ 0,001), un to var izmantot kā ANB markieri. 